Prace Komisji Geografii Komunikacji PTG

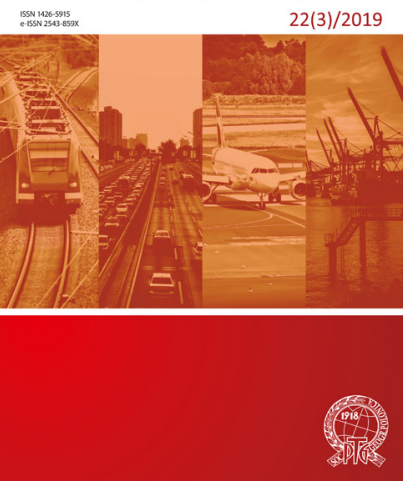

\section{Transport Geography Papers of Polish Geographical Society}

$2019,22(3), 64-72$

DOI: 10.4467/2543859XPKG.19.018.11284
Received: 31.01 .2019

Received in revised form: 14.08 .2019

Accepted: 30.08 .2019

Published: 30.09.2019

\title{
CHARACTERISTICS OF CONSTRUCTION AND OPERATION OF TROLLEYBUS SYSTEMS IN THE WORLD
}

\section{Charakterystyka tworzenia i funkcjonowania systemów trolejbusowych na świecie}

\section{Pavel Stepanov}

Russian Academy of Sciences, Institute of Geography, Department of Social and Economical Geography, Staromonetny lane 29, 119017 Moscow, Russian Federation

e-mail: pav.stepanov2012@yandex.ru

\section{Citation:}

Stepanov P., 2019, Characteristics of construction and operation of trolleybus systems in the world, Prace Komisji Geografii Komunikacji PTG, 22(3), 64-72.

Abstract: Trolleybus transport was a very popular mode of transport in the past. Trolleybus systems have existed in more than 70 countries of the world. The maximum number of trolleybus systems (366) was operated in 1949. Today, this number is only 286 , and mostly it is popular in the post-socialistic countries. Nevertheless, trolleybus systems of different countries have significant differences in the terms of construction and are being exploited in different ways.

Key words: rolling stock, trolleybus line, trolleybus system 


\section{Introduction}

Trolleybus systems in different cities of the world have various specifics in construction and operation. All countries of the world, where the trolleybus was ever used, were divided by the author into 4 specific types, which characterize the principles of construc- tion, operation and the probable reasons for the closure of the trolleybus in their cities:

- "Market type";

- "Planned type";

- "Introductory type";

- "Exceptions".

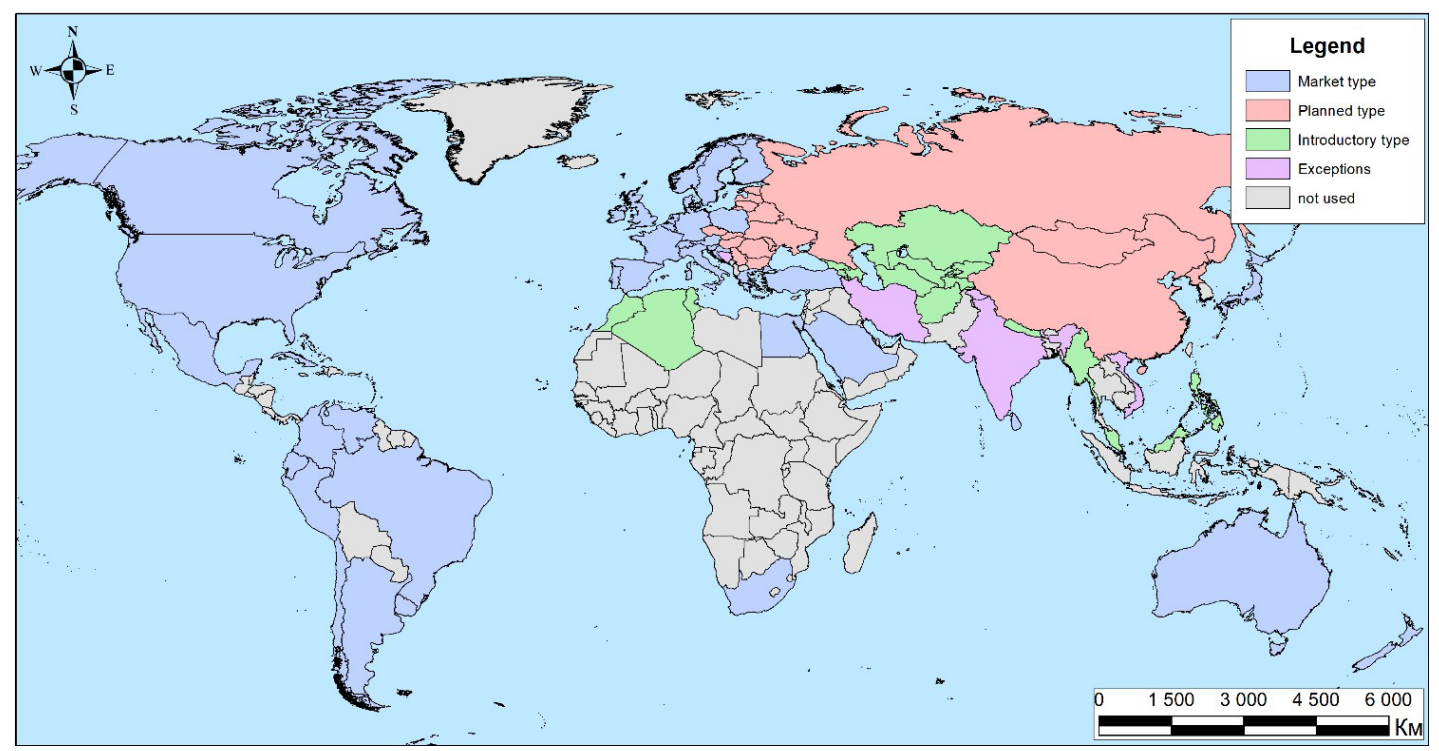

Fig. 1. Types of countries of the world on the principles of construction and operation of trolleybus systems.

Source: compiled by the author.

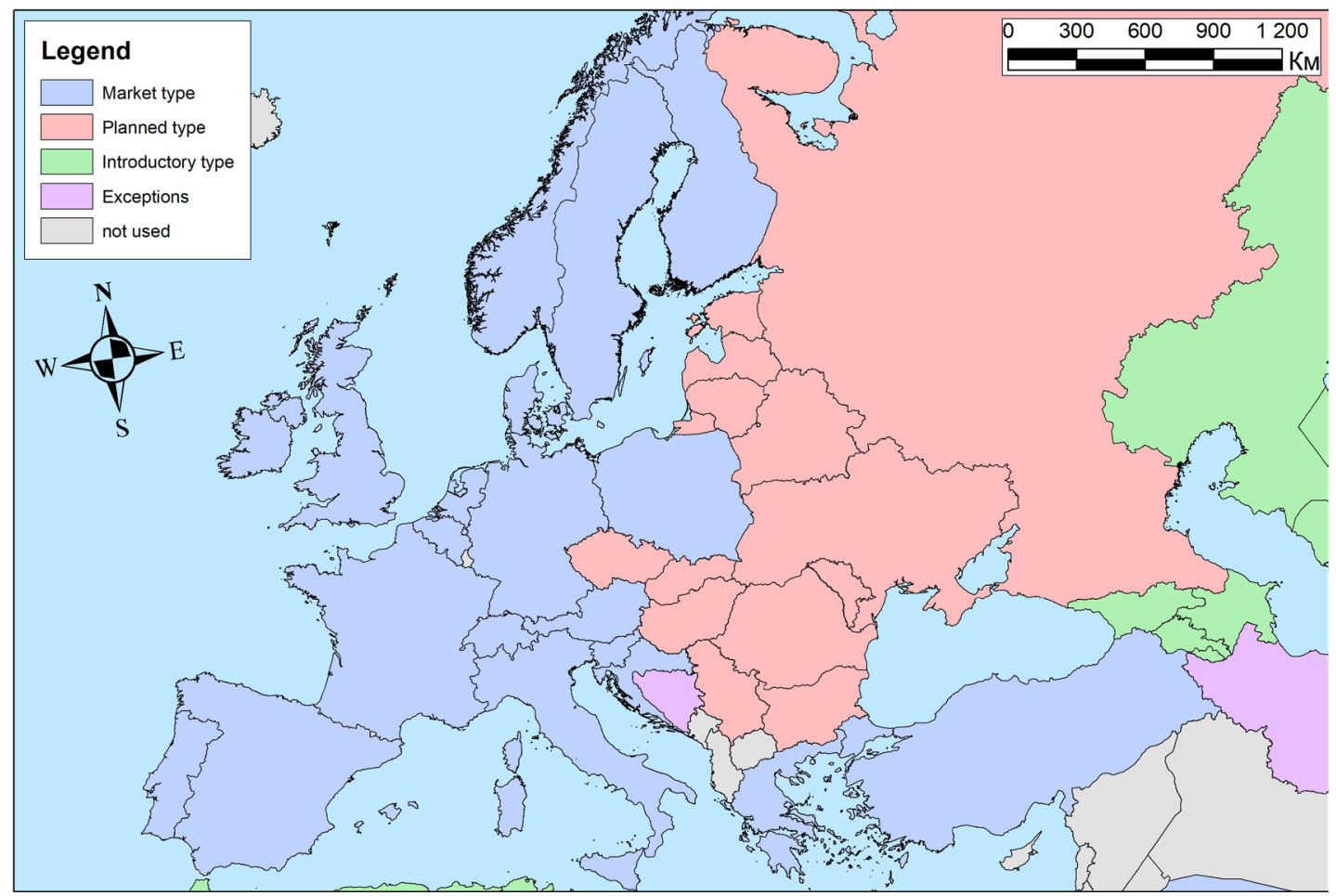

Fig. 2. Types of countries of Europe on the principles of construction and operation of trolleybus systems.

Source: compiled by the author. 
The assignment of a country to one of the types occurred depending on the specifics of its trolleybus systems. If $80 \%$ or more of the systems are characteristic for this type, then the whole country belongs to it. Otherwise, the country is of the type of "exceptions" (Fig. 1; Fig. 2).

Assignment of type to the systems occurred based on the following criteria:

- Systems opening period;

- Systems closing period (if relevant);

- Reasons for opening the system;

- Reasons for closing the system (if relevant);

- Features of the rolling stock renewal.

All ever existing systems were analyzed according to these criteria. Values of the criteria are given in the Tab. 1. following technical progress. The economic factor played a main role.

In countries of this type, the trolleybus was developed the most rapidly in the 1930s - 50s. This was because the electric motor was the most advanced type of engine at that time. The tram seemed outdated technology, and the trackless transport seemed more modern. In addition, the Second World War contributed to the development of electric transport, when the warring countries had a shortage of fuel.

In the 1960s, internal combustion engines became more complete, and oil became cheaper. Neither the trolleybuses nor the trams could compete with the buses in the mobility. Therefore, there was a massive replacement of electric transport by gasoline or diesel type of rolling stock during this period.

Tab. 1. The criteria of system's types.

\begin{tabular}{|l|l|l|l|}
\hline \multicolumn{1}{|c|}{ Criterion } & \multicolumn{1}{|c|}{ Market type } & Planned type & Introductory type \\
\hline Systems opening period & $1930 \mathrm{~s}-50 \mathrm{~s}$ & $1950 \mathrm{~s}-80 \mathrm{~s}$ & As well as in the parent state \\
\hline Systems closing period & Until 1980 & $\begin{array}{l}10 \text { to } 20 \text { years after the country } \\
\text { gained independence }\end{array}$ & $\begin{array}{l}\text { Aconomic reasons (electric } \\
\text { motor was cheaper) and citizen } \\
\text { behavior model }\end{array}$ \\
\hline $\begin{array}{l}\text { Reasons for opening the } \\
\text { system }\end{array}$ & $\begin{array}{l}\text { Economic reasons (electric } \\
\text { motor was cheaper) }\end{array}$ & $\begin{array}{l}\text { Economic reasons (ICE became } \\
\text { more profitable) }\end{array}$ & Lack of funding \\
\hline $\begin{array}{l}\text { Features of the rolling stock } \\
\text { renewal }\end{array}$ & At a time & Gradually & Lack of funding \\
\hline
\end{tabular}

Source: compiled by the author based on Bartłomiejczyk, Połom, 2013; Połom, 2018; Rasiński, 2018.

A more detailed description of these criteria is provided in the type analysis below.

\section{1. "Market type"}

The market type was given such name because it includes countries with a market economy. They had this type of economy in all the periods that we identified. It includes the United States, Western Europe, Japan, Canada, Australia, some countries in Asia and Latin America.

The market type was given such name because it includes countries with a market economy. They had this type of economy in all the periods that we identified. It includes the United States, Western Europe, Japan, Canada, Australia, some countries in Asia and Latin America.

In cities of these countries the trolleybus systems were developed together with the city and its transport network. Systems were devolved and degraded
This happened massively, and the main reason was economic. Often the systems were closed at a time without gradual reduction. Usually, the closure happened at the moment when the operational resource of trolleybus rolling stock was ended (in countries with market economies, the rolling stock is replaced at a time). Thus, at a certain point in time, the old trolleybuses were replaced with new buses, and the rest of the infrastructure was dismantled. The average service life of the trolleybus is 20 years. Consequently, any trolleybus transport system in a country of market type have a chance to close approximately every 20 years. The trolleybus systems of these countries operate 20,40,60, etc. years old (Box, 2010).

After the 1973 oil crisis, the shutdown rate of trolleybus transport was sharply reduced. Firstly, it was because the most systems have already been closed by this time. In some cases, the trolleybuses continued to operate for economic reasons. For example, in cities with crossed relief the using of trolleybuses is 
more economically efficient than buses. In addition, an important factor was increased price for oil and automobile fuel. A trolleybus is less dependent on oil quotations because it uses electricity, which can be generated by coal or hydropower. For this reason, existing systems have been saved.

Canada is a typical example of a market type country. The trolleybus operated in 15 cities of country (there were two systems in Toronto). Currently, the trolleybus system operates only in Vancouver (Tab. 2). Most of the systems of this country were opened in 1930s-50s and were closed before the oil crisis.
Similar processes typical for other countries of this type.

Currently the economic situation in countries of market type is generally favorable for trolleybus systems. The environmental aspect is very important for the transport in the modern world. In addition, new ways of generating energy have appeared (biofuel, solar and wind power), which is combined with modern environmental doctrine.

As a result, the number of trolley buses is constant (few systems are being closed, but some new systems are being opened). New trolleybus lines are

Tab. 2. List of trolleybus systems in Canada.

\begin{tabular}{|l|c|c|c|}
\hline \multicolumn{1}{|c|}{ City } & Opening date & Closing date & Years of operation \\
\hline Calgary & 1947 & 1975 & 28 \\
\hline Cornwall & 1949 & 1970 & 70 \\
\hline Edmonton & 1939 & 1969 & 20 \\
\hline Halifax & 1949 & 1992 & 42 \\
\hline Hamilton & 1950 & 1973 & 26 \\
\hline Kitchener & 1947 & 1966 & 8 \\
\hline Montreal & 1937 & 1959 & 19 \\
\hline Ottawa & 1951 & 1966 & 26 \\
\hline Regina & 1947 & 1974 & 25 \\
\hline Saskatoon & 1948 & 1972 & 3 \\
\hline Thunder Bay & 1947 & 1925 & 46 \\
\hline Toronto & 1922 & 1993 & 71 \\
\hline Toronto & 1947 & in operation & 4 \\
\hline Vancouver & 1948 & 1926 & 32 \\
\hline Windsor & 1922 & 1970 & \\
\hline Winnipeg & 1938 & 2009 & \\
\hline
\end{tabular}

Source: North American Trackless..., 1973; Urban Electric Transit: http://transphoto.ru [05.05.2019].

The trolleybus system in Hamilton is an example of rolling stock renewal, which is typical for countries of this type. Hamilton system used only three models of trolleybuses from two periods (North American Trackless..., 1973):

1) CCF / Brill T48 is a typical trolleybus model for North America, produced in 1940s - 60s.

2) Flyer E700A and Flyer E800B are typical models for the USA and Canada, produced in 1970s - 80s.

Fleet was purchased in large quantities (in fact, the fleet was replaced completely). Hamilton's system was closed in 1992, when the operational resource of second-generation trolleybuses rolling stock was ended (Tab. 3). Diesel buses were bought instead. opened usually in small towns (less than 500 thousand people). This is due to the fact that light rail transit (LRT) systems is more popular. However, they are often too expensive for small towns and trolleybus is a cheaper alternative. Moreover, LRT is a trunk transport for huge passenger traffic (that does not exist in small towns).

\section{2. "Planned type"}

Trolleybus transport began to develop later in the countries of the planned type than in the countries of the first type. The most rapid development of systems in these countries took place in the 1950s - 
Tab. 3. List of trolleybus systems in Canada.

\begin{tabular}{|l|c|c|c|c|}
\hline \multicolumn{1}{|c|}{ Model } & Built & Withdrawn & Years in operation & Quantity \\
\hline CCF/Brill T48 & 1950 & 1978 & 28 & 18 \\
\hline CCF/Brill T48A & 1951 & 1978 & 27 & 30 \\
\hline Flyer E700A & $1972-1973$ & 1992 & 20 & 40 \\
\hline Flyer E800B & 1978 & 1992 & 14 & 16 \\
\hline
\end{tabular}

Source: North American Trackless..., 1973; Urban Electric Transit: http://transphoto.ru [05.05.2019].

80s. Such countries include Russia, Ukraine, Belarus (at that time they were part of the USSR), China, the DPRK, the Czechia and Slovakia (in the past, as part of Czechoslovakia). At the same time, the last two countries are interesting because the peak of the opening of trolleybus systems in these countries was in the 1940s and 1990s respectively (Box, 2010).

A typical country of the planned type is Belarus, where there are seven trolleybus systems. All of them were opened in 1950s - 80s. (Tab. 4). Trolleybus systems in the cities of Belarus have not been closed yet. (large factories and plants). The small towns of the USSR (with a population of about 100 thousand inhabitants) demonstrate this most clearly. The trolleybus was opened there mainly in the 1970s-80s. Examples of such cities: Volgodonsk, Miass, Novokuibyshevsk, Novocheboksarsk, Rubtsovsk and others. The chemical plant was the most common enterprise where the trolleybus was built. It was due to that city leaders tried to reduce the environmental pressure in cities where there were harmful manufacturing. In general, the trolleybus was associated with ecology

Tab. 4. List of trolleybus systems in Belarus.

\begin{tabular}{|c|c|c|c|}
\hline City & Opening date & Closing date & Years of operation \\
\hline Bobruisk & 1978 & in operation & 38 \\
\hline Brest & 1981 & in operation & 47 \\
\hline Gomel & 1962 & in operation & 67 \\
\hline Grodno & 1974 & in operation & 49 \\
\hline Minsk & 1952 & in operation & 41 \\
\hline Mogilev & 1970 & in operation & 45 \\
\hline Vitebsk & 1978 & in operation & 4 \\
\hline
\end{tabular}

Source: Box, 2010; Urban Electric Transit: http://transphoto.ru [05.05.2019].

Poland does not belong to this type because despite of its socialist model of the economy in the second half of the 20th century, the development of trolleybus transport here took place like in countries with market economy (Połom, 2017; Połom, 2018).

Cuba also belong to the market type in this typology, since the trolleybus appeared there before the Cuban revolution, and was closed because of it.

As it was already mentioned, the reason for the construction of trolleybus systems in the cities of these countries was not only the economic component, but also the peculiarities of citizen behavior model of these countries. Trolleybus lines connected mainly large residential areas with production sites and a more favorable environmental situation in the socialist countries (Tarkov, 2000).

However, trolleybus transport in the USSR and other socialistic countries were being developed according to the principle "residential area - factory" not only in small towns. The fact is that the larger the cities are, the greater its transport systems are. Therefore, many other intercity links distort this principle, and it becomes not so clear. For example, in such a large city as Moscow, where the trolleybus system covers almost the whole territory of the city, it is impossible to designate main reason of construction of the trolleybus lines. In Moscow, trolleybus lines replaced a huge network of tram routes mainly, be- 
cause the trolleybus was considered a more modern mean of transport. However, large trolleybus systems in huge cities such as Yekaterinburg (at that time Sverdlovsk) and Rostov-on-Don originate from lines to large industrial enterprises (Uralkhimmmash and Selmash plants, respectively) (Tarkov, 1990).

Since the directions of passenger traffic in the cities of socialist countries have not changed during a long time, one of the trolleybus's disadvantage (inflexibility of routes) was irrelevant here. However, in the 1990s, when the ex-socialist countries chose a market type of economy, many enterprises were closed there, and the concentration of passenger traffic changed directions. This led to a crisis of trolleybus systems in the cities of the post-socialist countries. The crisis has particularly affected the post-Soviet countries, such as Russia, Ukraine and to a lesser extent Belarus. However, not many planned type systems have been closed by now, because such systems have a large volume of durability and they cannot be closed immediately, as it has happened in countries of the market type.

The fact is that most of the trolleybus systems in socialistic countries had been operating for several decades before the politic system was changed there. In socialistic period the systems were being expanded constantly, so there was a constant need for new rolling stock. As a result, the new trolleybuses arrived gradually, and they had different date of manufacture. The old rolling stock was replaced at the time when the newer one had not yet exhausted its resource. So the replacement did not take place at the same time, but gradually, as a result, such replacement was permanently. The planned economy also contributed to this: it was known how many trolleybuses would be purchased for permanent replacement of rolling stock. Thus, the closure of the system due to exhaustion of resource was impossible. The fact that a large number of trolleybus systems were closed in Romania in the 21st century confirms this. In many cities of this country trolleybus lines appeared in the late 1980s - early 1990s. Then a crisis began in the post-socialist countries, so new lines were not built. Thereby the new Romanian systems were not expanded. As a result, trolleybuses, which have been purchased for opening systems, operated on the routes. This led to rolling stock had exhausted their resources at the same time, and authority decided do not buy new trolleybuses as a rolling stock, but replace them with buses.

Despite that the most of the post-socialistic countries have the market type of economy for more than 25 years, the practice of rolling stock gradually updating is relevant for then even now. One of the reasons for that is the lack of funds for replacing a large number of trolleybuses at the same time, so transport companies continue to renew the park gradually. Therefore, such systems are more stable than systems where large batches of trolleybuses are purchased at the same time, and there is a risk of closing of the system every 20 years. If system of planned type has problems, then such a system begins to degrade and shrink (these processes are typical for the most systems in Russia), but it needs a lot of time for the system to be closed completely. Therefore, there is a possibility that the situation will be improved and the system won't be closed, but it will become smaller. The "vitality" of trolleybus systems of planned type is evidenced by the fact that no one post-socialistic country has lost all its trolleybus systems entirely.

Brest (Belarus) is an example of the gradual renewal of the trolleybus fleet. Currently five models of trolleybus are used in the city. All of them was built from 1999 to 2017 (Tab. 5). That means that Brest buys small lots of trolleybuses (about 5 cars) annually. Thereby fleet is renewed continuously. This situation is typical for many cities in post-socialist countries.

Tab. 5. Trolleybus rolling stock in Brest (Belarus) in 2019.

\begin{tabular}{|l|c|c|}
\hline \multicolumn{1}{|c|}{ Model } & Built & Quantity \\
\hline BKM 221 & $2008-2010$ & 21 \\
\hline BKM 321 & $2005-2017$ & 29 \\
\hline BKM 201 & $1999-2005$ & 9 \\
\hline MAZ-ETON T103 & $2008-2011$ & 9 \\
\hline BKM 32100A & $2013-2014$ & 6 \\
\hline Total & $1999-2017$ & 74 \\
\hline
\end{tabular}

Source: Urban Electric Transit: http://transphoto.ru [05.05.2019].

However, many systems of this type have changed the specifics recently. As a result, they have become similar to the systems of the market type. There are two reasons for such transformations:

a) The countries of Eastern Europe, which had joined the EU at the beginning of the XXI century, began to receive money from the budget of the European Union. Significant funds are allocated for the development of public transport (especially environmentally friendly) in the new EU countries. As a result, many cities were able to replace the rolling stock almost at a time. The best example is Bratislava in Slovakia. Such renewal is widespread in the cities of Bulgaria, but mainly in small systems. In large trolleybus systems of cities in the 
Eastern Europe, it is impossible and inefficient to replace all trolleybuses at the same time, so they remain very stable. In the Czech Republic, gradual renewal is typically for too small systems too (about five trolleybuses per year).

b) In the cities in the post-Soviet countries a lot of trolleybus systems were degraded, but there are attempts to restore them. For this, many trolleybuses were purchased at a time, and all the old ones were retired. Such systems have new rolling stock with similar date of manufacture. However, if in the future (in 20 years from the date of purchase) new massive renewal will not been occurred, such systems will be closed, like in the countries of the first type. Examples of such cities: Belgorod, Tolyatti, Voronezh.

The same processes occur in China as well as in the countries of Eastern Europe.

Currently, the number of planned-type trolleybus systems is declining, either due to the economy transformation into market-type systems or due to closure. Also new systems are not being built, so we can say that this type will disappear soon (systems will be closed or transformed).

\section{3. "Introductory type"}

The third type of countries is called introductory, and it includes countries that in the past were the colonies of the developed West countries, as well as non-European republics of the former USSR. The peculiarity of this type of countries is that trolleybus transport were developed there thanks to the colonial authorities or the Soviet government only. After these countries gained independence, they could not exploit the trolleybus in their cities. As a result, trolleybus disappeared almost or completely there.

In the postcolonial countries, the main period of closure was 1960-1970s, several years after independence. In the post-USSR countries, it happened much later - in the late 2000s.

An example of a country of introductory type is Uzbekistan, where 9 out of 10 trolleybus systems was opened in the Soviet period. (Tab. 6). All of them were closed between 2002 and 2010. Thus, they closed 10 to 20 years after the country gained independence.

This type of country is nothing special. One can only say that the trolleybus transport was brought artificially here. Therefore, it disappeared shortly after the local authorities began to operate the public transport in the cities.

The degradation of trolleybus systems in the countries of introductory type occurred at the same time
Tab. 6. List of trolleybus systems in Uzbekistan.

\begin{tabular}{|l|c|c|c|}
\hline \multicolumn{1}{|c|}{ City } & $\begin{array}{c}\text { Opening } \\
\text { date }\end{array}$ & $\begin{array}{c}\text { Closing } \\
\text { date }\end{array}$ & $\begin{array}{c}\text { Years of } \\
\text { operation }\end{array}$ \\
\hline Almalyk & 1967 & 2009 & 42 \\
\hline Andijan & 1970 & 2002 & 32 \\
\hline Bukhara & 1987 & 2005 & 18 \\
\hline Ferghana & 1971 & 2003 & 32 \\
\hline Jizzak & 1997 & 2010 & 13 \\
\hline Namangan & 1973 & 2010 & 37 \\
\hline Nukus & 1991 & 2007 & 16 \\
\hline Samarkand & 1957 & 2005 & 48 \\
\hline Tashkent & 1947 & 2010 & 63 \\
\hline Urgench-Khiva & 1997 & in operation & 22 \\
\hline
\end{tabular}

Source: Box, 2010; Urban Electric Transit: http://transphoto.ru [05.05.2019].

as in the countries of market and planned types (in the postcolonial countries and post-USSR countries, respectively). However, the cause of the degradation was different, and it was at a faster.

Also, Nepal belongs to this type, although it was not controlled by anyone officially. Nevertheless, trolleybus in Kathmandu was appeared thanks to People's Republic of China. China helped to build the system and supplied the rolling stock. Thereby when the Chinese side stopped supporting of the trolleybus in Kathmandu, it was closed soon. This is another example of artificial introduction.

A similar situation occurred in Afghanistan, where the Kabul's trolleybus was built thanks to Czechoslovak specialists, and Afghans have failed to operate the system in order.

\section{Type "exceptions"}

The last type is called "exceptions", because in some countries it is difficult to understand the causes of the development and degradation of trolleybus systems. Military actions or the unstable political and economic situation in the country also make analysis difficult. Often in such countries, there are too few systems to refer to one of the three types listed above.

Let's consider all countries, which have related to this type, more detail.

Bosnia and Herzegovina is a country with an artificial statehood, where civil war took place. Now the existence of this state depends on outside help. Therefore, the existence of a trolleybus system in Sarajevo is mainly due to the help of West Europe substantially (Wołek, Wyszomirski, 2013).

Another such case is Iran. A trolleybus exists only in Tehran there. It was opened in 1992. Iran has never been a socialistic country, but it does not live accord- 
ing to the market laws, because the sanctions has been applied to the country for a long time.

It is impossible to say exactly about the reasons for the construction and closure of the trolleybus systems in India. The British opened the system in Delhi. Trolleybus have been opened after independence in Calcutta and Mumbai. In Mumbai a trolleybus was opened with support from Czechoslovakia. So, India can be classified into all types: market, planned and introductory.

Exceptions include Vietnam also, where the trolleybus in Hanoi was opened for the same reasons as in many others socialistic countries (it has replaced a streetcar). Then Vietnamese could not operate the system in order and the trolleybus was closed soon.

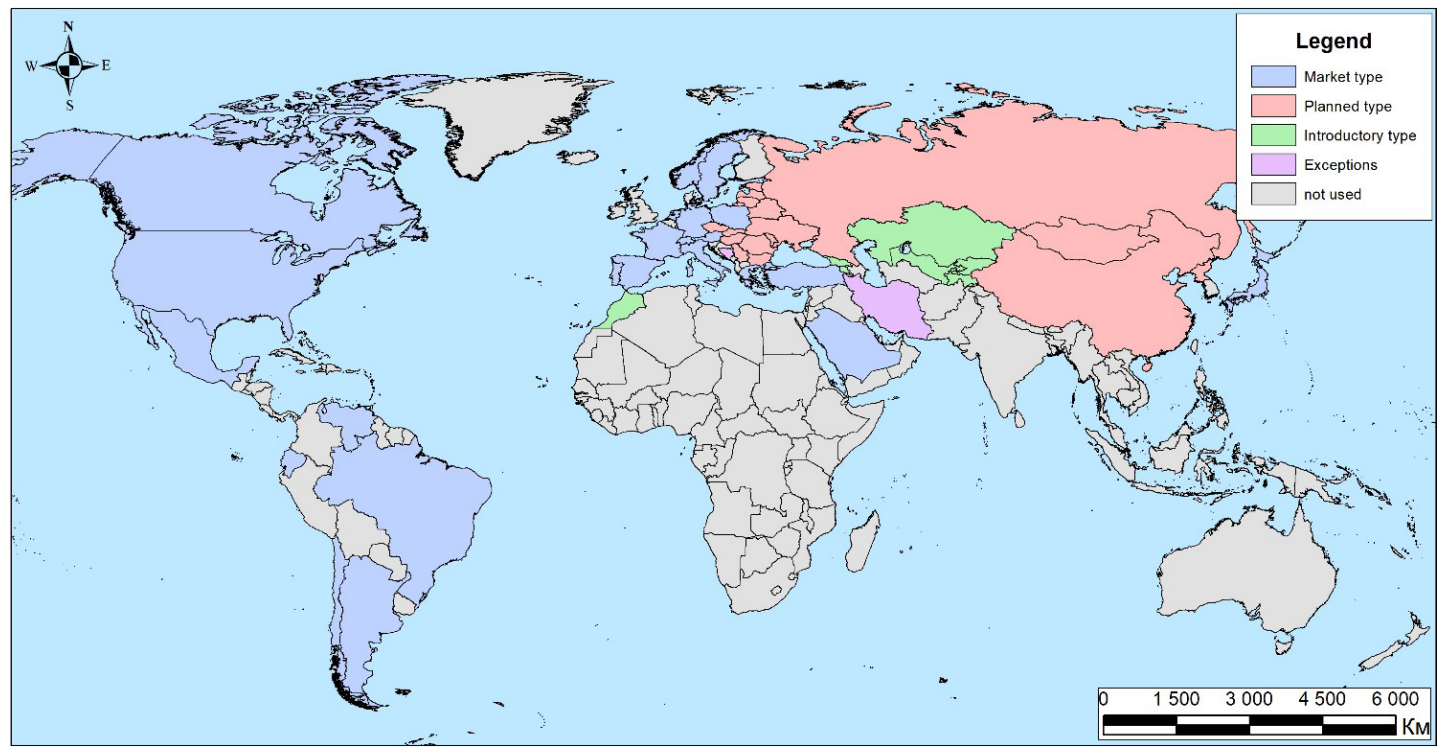

Fig. 3. Types of countries of the world on the principles of construction and operation of trolleybus systems in 2018. Source: compiled by the author.

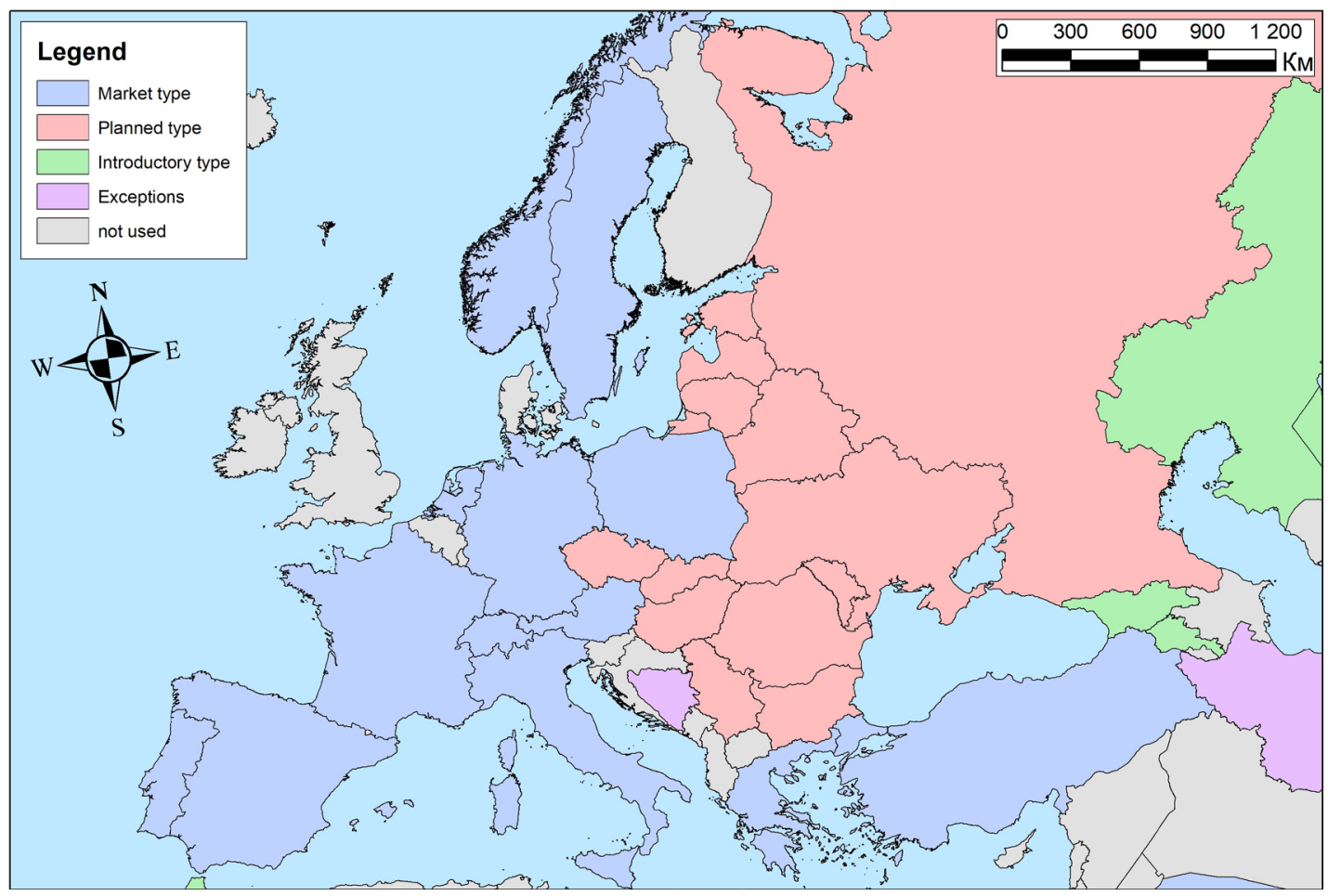

Fig. 4. Types of countries of Europe on the principles of construction and operation of trolleybus systems in 2018. Source: compiled by the author. 


\section{Conclusions}

Thus, we can draw several conclusions. In the past, systems were built, developed and degraded according to the principles and characteristics of their type: market, planned, introductory. The most popular in the countries of the first type trolleybus was in the middle of the last century. The peak of trolleybus development was in the 1990s in countries of planned type. In the countries of introductory type, the largest number of trolleybus systems existed in the middle of the 20th century (for colonial countries) and in the 1990s (for post-USSR countries).

Currently, the number of trolleybus systems remains almost constant in the countries of the market type. But the number of systems is significantly reduced in the countries of the second and especially the third type (Fig. 3, Fig. 4). The introduction type ceased to exist in fact. The number of systems in countries of the planned type should be significantly reduced in the near future: some of them will close, while others will transform (they will become the systems of the market type).

\section{Literature}

Bartłomiejczyk M., Połom M., 2011, Determinants of functioning of trolleybus transport in selected cities of the European Union, Wydawnictwo Bernardinum, Pelplin.

Box R., 2010, Another decade of mixed fortunes, Trolleybus Magazine, 290, 26-34.

http://transphoto.ru [05.05.2019]

Połom M., 2017, Przemiany funkcjonowania komunikacji trolejbusowej w Polsce w latach 1989-2013, Wydawnictwo Bernardinum, Pelplin.

Połom M., 2018, Trends in the development of trolleybus transport in Poland at the end of the second decade of the 21st century, Prace Komisji Geografii Komunikacji PTG, 21(4), 57-68.

Rasiński T., 2018, Trolleybus communication as one of the alternatives to modern public transport, Autobusy-Technika, Eksploatacja, Systemy Transportowe, 12, 213-216. (DOI 10.24136/atest.2018.384)

Tarkov S., 1990, Tram and trolleybus in cities of the USSR, RAN, Moscow.

Tarkov S., 2000, Empire of the Trolleybus: Vol. 1 - Russia, Rapid Transit Publications, London.

Trolleybus Data Book, Trolleybus Bulletin № 105, 1973, North American Trackless Trolley Association, Louisville.

Wołek M., Wyszomirski O. (eds.), 2013, The trolleybus as an urban means of transport in the light of the Trolley project, Wydawnictwo Uniwersytetu Gdańskiego, Gdańsk. 